\title{
Paradox of Poverty in the Midst of Abundant Resources: The Politics of Oil Resources and Renewed Insurgency in the Niger Delta Region of Nigeria
}

Boris Happy Odalonu: Department of Political Science, Federal College of Education Eha-Amufu, Enugu, Nigeria.

\begin{abstract}
Nigerian state depends majorly on oil resources for her economic survival. Over $85 \%$ revenue generation to the Nigerian government are derived from oil production in the Niger Delta. In spite of this, Niger Delta region illustrates a paradox of poverty in the midst of abundant resources. The region remains one of the poorest and least developed parts of the country. The region suffers from environmental pollution, pervasive poverty and underdevelopment. These culminated to series of peaceful agitations to draw the attention of the government for solution to their challenges but due to the insensitivity of the government and oil companies operating in the region to their plight it degenerated to violent agitations, hence the insurgency and militancy in the region. The effects of all these were the disruptions of oil and gas production, reduced national revenue, withdrawal of foreign capital, kidnapping of expatriate oil company staff and so on. In a bid to curb the insurgency and militancy in the region, the Federal Government initiated the amnesty programme in 2009. Seven years after, the issues of environmental degradation, youth unemployment, poverty and underdevelopment that led to militancy and insurgency in the region remain unresolved. Thus, there was renewed insurgency from January to December, 2016 in the region. The paper argues that, granting of amnesty to the militants is a temporarily solution to the problems and until the grievances of the region are sincerely tackled by the government, the issues of militancy and insurgency will remain unabated and may degenerate.
\end{abstract}

Key words: Poverty, Politics, Conflict, Insurgency, Oil resources, Niger Delta, Nigeria.

\section{Introduction}

The Niger Delta region has drawn both local and international attention in Nigeria as a result of insecurity and militancy. This region has been at the centre of struggle for a number of issues pertinent to the people of the region (Ojo, 2012). Niger Delta being an oil-rich region where oil exploration and extraction has been going on for over five decades, the people in the region believe they deserve more attention from the Federal Government, Oil Companies operating in the region and other stakeholders (Fagbadebo and Akinola, 2010; Ojo, 2012). Over the years, the activities of oil exploration and extraction in region have destroyed the means of livelihoods of the people. This had resulted to conflicts between Niger Delta people, the Oil Companies and the Federal Government. The climax of these conflicts was the formation of different groups agitating for the amelioration of Niger Delta environment. However lack of attention from the appropriate authorities for the region further degenerated into armed conflict characterized by kidnapping, oil theft, oil bunkering, bombing of oil installations and other negative activities by the militant groups in the region.

Since then, the Niger Delta region had been the epicenter of a low intensity war owing largely to the insurgency waged by militant youths and the counter-insurgency by security agents deployed by the state to protect geo-strategic oil resources (Tonwe and Aghedo, 2013). Niger Delta resource-based insurgency became

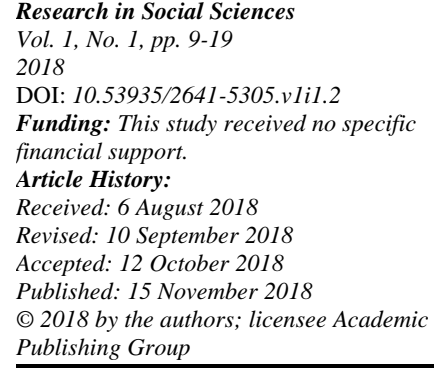


intensified in the 1990s when series of protests by environmental activists and resource control agitators were violently repressed by security forces (Odomovo, 2014). The region was almost ungovernable. Hostagetaking of foreign oil workers, sabotage of oil pipelines and other petroleum production facilities as well as other vices were the order of the day. Militants in Nigeria's oil-rich Niger Delta began a campaign of kidnappings and pipeline bombings in the early 2000s, upset over pollution and the region's endemic poverty (Hinshaw, 2012). After almost two decades of protests, violence and armed resistance in which civil society, communities and militants played the vanguard roles, accompanied by massive militarization and military actions, the Niger Delta entered into a new period in its history in October 2009. Based on the promise of the federal government to address the problems of the Niger Delta as part of a seven point agenda, the militants in the region accepted a federal amnesty, disarmament and cessation of hostilities (Ezeibe and Nnamani, 2010; Obi and Rustad, 2011; Ikelegbe and Umukoro, 2014).

Perturbed by the protracted insecurity and crisis in Niger Delta, the Federal Government of Nigeria under the leadership of late President Yar' Adua on June 25, 2009, granted unconditional amnesty to the agitators in the region (Tonwe and Aghedo, 2013; Ezeibe and Nnamani, 2010; Obi and Rustad, 2011). The militants were expected to take advantage of a 60-day window (August 6 to October 4, 2009) to surrender their arms and ammunitions and sign the amnesty register as evidence of their acceptance of the peace deal (Tonwe and Aghedo, 2013). The term of the amnesty included the willingness and readiness of these agitators to surrender their arms, unconditionally renounce militancy and sign an undertaking to this effect. In return, the government pledged its commitment to institute programmes to assist the disarmament, demobilization, rehabilitation and reintegration of repentant ex-agitators (Ibaba, 2011; Oluwaniyi, 2011; Oluduro and Oluduro, 2012; Ekumaoko, 2013). The cardinal objective of granting amnesty to the Niger Delta agitators was to stabilize, consulate and sustain security condition in the region as pre-requisite for promoting economic development in the area and in the country as a whole (Onwukwe, 2013). After a government-sponsored amnesty program in 2009 , violence dropped and production went back up. But oil theft, a lucrative criminal industry, drew many militants, new and old back into the delta's winding creeks. While richly remunerated former kingpins profess to have left the oil-theft business, many former militant foot soldiers that are paid less or not at all by the amnesty, and have few job prospects, continue to pursue prosperity by tapping pipelines (Hinshaw, 2012).

Apart from oil theft and other forms of criminality in the region, new militant groups have sprung out and they have continuously bombed oil facilities and pipelines in the region. Why has the Nigerian government been unable to contain and eliminate these threats to its vital economic and security interest to date? What can be done to curb oil-based insurgency in the Niger Delta region? Thus, this paper explores the politics of oil resources and insurgency, the causes of the renewed insurgency in post amnesty era in the Niger Delta region and its implication. The paper also attempts to examine the impact of amnesty programme in mitigating oilbased insurgency in the Niger Delta region.

\section{Methodology}

This study is an analytical investigation conducted with the used of qualitative research methods. The data employed for the study were gathered from secondary sources such as newspapers, magazines, journal articles, bulletins, periodicals, government publications, books, internet search, and documentary materials among others. The study utilized both content analysis and trend analytical techniques for the analysis of data. As such the information employed for analysis in the study were carefully extracted from logical chains of evidence presented in journal papers, conference papers, periodic papers, edited books, internet search, documentary materials among others

\section{Niger Delta Region}

There are various conceptualizations of Niger Delta. Firstly Niger Delta is seen as a colonial creation of province in 1923 which encompasses formal Brass, Degema, Ogoni, Yenagoa, and Western Ijaw divisions. Secondly Niger Delta is defined by the Willinks Commission Report of (1958) which engineered the Niger Delta Development Board (NDDB) Act, 1960 as the region covering 70, 000, sq km, comprising old administrative divisions which metamorphosed into present day Bayelsa, Rivers, Akwa-Ibom, Cross Rivers and Delta state. Thirdly, Niger Delta region is seen as synonymous with a geopolitical frame of the SouthSouth region defined by the political restructuring of General Sani Abacha regime which consists of six states 
namely: Akwa Ibom, Bayelsa, Cross River, Delta, Edo and Rivers. Lastly, the NDDC Act (2000) described the Niger Delta region as synonymous with nine oil producing states in Nigeria which are; Abia, Akwa-Ibom, Bayelsa, Cross River, Delta, Edo, Imo, Ondo and Rivers (Kimiebi, 2010; Garuba, 2012).

Arguably, Okoli (2013) noted that the core Niger Delta states are Bayelsa, Delta and Rivers States while the peripheral Niger Delta states are Abia, Akwa-Ibom, Cross Rivers, Edo, Imo and Ondo States. This collaborate with the view of Obi and Rustad (2011) that three states namely, Rivers, Bayelsa and Delta states, make up the Niger Delta in terms of the quantity of oil production and petroviolence. As it stands, Niger Delta is a home of over 31 million people, made up of multiethnic nationalities, such as Ikwerre, Ogoni, Ijaw, Ogba, Ahoada, Urhobo and Itsekiri, Efik, Ibibio, Annang, Oron, Isoko, Ukwuani, kalabari, Ekwere, etc., speaking about 250 different dialects (Wikipedia, 2013; Okurebia and Daniel, 2014). The ethnic nationalities in the Niger Delta region are referred to as minorities in relation to the three major ethnic groups in the Nigerian Federation and they are mainly farmers and fishermen (Obi-Ani, 2004; Egwemi, 2010). The region occupies a total area of about 75, $000 \mathrm{~km}$ and makes up 7.5\% of Nigeria's land mass which cut across over 800 oil producing communities with an extension network of over 900 oil producing wells and several petroleum production related facilities (wikipedia, 2013; Okurebia and Daniel, 2014).

The Niger Delta accounts for over $85 \%$ of Nigeria's oil production with over 600 oil fields, 5,284 oil wells, 10 oil and gas export terminals, 275 flow stations 10 gas plants, and massive liquefied natural gas and is the take-off point of over 700 kilometers of pipelines across the country (Ibaba, 2009; Aghedo, 2011). Oil and gas resources from the region provide 85 per cent of government revenue, 95 per cent of foreign exchange earnings and 96 per cent of export revenues (Ibori, 2009). The Niger Delta is one of the world's largest wetlands, one of the 20 major deltas in the world and Africa's largest delta and perhaps, the richest in the world in terms of oil and gas reserves, covering some $70000 \mathrm{~km} 2$ (Badmus, 2010; Fagbadebo and Akinola, 2010). The Niger Delta region is reputed to be one of the most richly endowed wetlands in the world. In spite of its huge resource endowment, the Niger Delta region illustrates a paradox of poverty in the midst of abundant resources. Obi (1997) lamented that: "The region is by far the most central to the nation's economic and political survival," but paradoxically, it is one of the "poorest, least developed and reciprocated for its contributions to national wealth". The region has, in addition, a pervasive unemployment problem, especially among the youths and women. In fact, the region epitomizes one of the most extreme cases of poverty and unemployment level in the country (Orubebe, 2013).

\section{Politics of Oil and Conflict in the Niger Delta}

Oil and minerals-related conflicts are rooted in the inequitable social relations that govern the production and distribution of profits from oil, and its adverse impact on the fragile ecosystem of the Niger Delta. It involves the Nigerian state and oil companies on one side, and the people of oil producing communities in the Niger Delta, on the other. In contention is the oil-rich environment, the manner of distributing its wealth, and the survival of its inhabitants who depend on the ecosystem for their basic needs and livelihood. The host communities contend that because the oil is mined in their land, and they suffer from the pollution and environmental degradation attendant to oil production, they have a right to adequate compensation, a clean and safe environment, and a fair share of oil rents, while the state and its partners, the oil multinationals, insist on the optimization of rents and profits on the basis of modalities defined exclusively by the partnership and the law of the land (Oluwadare and Oyebode, 2013). Thus, the Niger Delta crisis has its roots in the age-long struggle of the Niger Delta people to 'rule' their destiny through self-determination and 'resource control' and this has manifested in various forms and colorations (Okoli, 2007). Similarly, Okoli (2013) stated that:

\footnotetext{
"The roots of crisis in the Niger Delta are not farfetched from the prevailing social, political, economic and ecological dialectics of the region. This has to do with state predation and terrorism, corporate buccaneerism and irresponsibility, environmental degradation and abuse, socio-economic and political deprivations and marginalization as well as mass impoverishment for which the Nigerian State and the oil multinationals are mutually culpable,"
}

Over the years since the discovering of oil in the Niger Delta region in 1956, there had been one form of struggle and youth agitation to another against the oil companies and Nigerian government on fundamental issues of environmental pollution and degradation, politics of marginalization and exclusion, pervasive

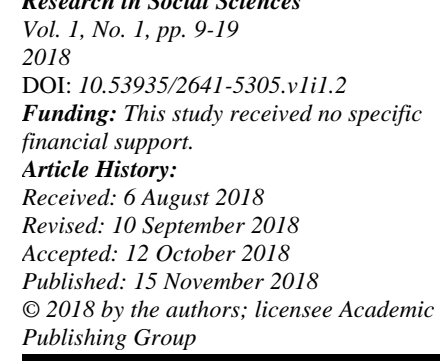


poverty and underdevelopment and massive youth unemployment in the region, etc., (Ikelegbe, 2010; Orubebe, 2013). The struggle over oil, particularly the quest to correct the perceived injustices embedded in the separation of those profit from the oil production and commoditization (MNCs and the Nigerian ruling elites) from others (dispossessed local inhabitants) whose land and waters the oil is extracted, has led to the violent agitation in the Niger Delta region (Obi, 2010).

The above assertions shows that the crises in the region were caused by a number of factors, which include environmental pollution and despoliation in the region, pervasive poverty and underdevelopment in the region, legislations of disempowerment and subjugation of the people of the region, desire for resource control and self-determination by the people of the region, and repression of the people and militarization of the region by the government (Aminu, 2013). Consequently, the agitation for environmental justice in the region led to the formation of the different groups such as the Movement for the Survival of Ogoni People (MOSOP) in August, 1990; the Kaiama Declaration that metamorphosed to the formation of the Ijaw Youth Council (IYC) in December 11, 1998; the Movement for the Survival of Ijaw Ethnic Nationality (MOSIEN); Egbema National Congress (ENC); Niger Delta Women for Justice (NDWJ); etc., (Oluduro and Oluduro, 2012; Ejovi and Ebie, 2013; Aminu , 2013).

\section{The Drive of Insurgency and Counterinsurgency in the Niger Delta}

The agitation of the control of oil wealth in the Niger Delta culminated into violent attacks and counterattack between the militants and military forces. The Niger Delta region that produce most of Nigeria's oil have suffered the costs of oil production in the form of underdevelopment and pollution, while sharing little in the benefits. From 2005 to 2009 , these frustrations fueled a violent insurgency, in which various armed groups bombed pipelines, stole oil, and kidnapped foreign workers, while engaging in rampant smuggling and piracy.

The Niger Delta struggle took a volatile dimension in the 1990s. The peak of these struggles and agitations were the formation of several violent militant groups like; the Niger Delta People's Volunteer Force (NDPVF), broke from the Ijaw Youth Council (IYC) in 2004 and was founded by Mujahid Dokubo-Asari and operated mostly in Rivers State, the Niger-Delta Liberation Force ( NDLF), led by John Togo, Niger Delta Vigilante (NDV), formed in Rivers state in 2003 by Ateke Tom, the Niger Delta Strike Force (NDSF), formed in 2005 by Farah Dagogo, and Operated under the MEND umbrella in Rivers State, the Joint Revolutionary Council (JRC) led by Tompolo and others, the Outlaws, formed by Soboma George, Egbesu Boys of Africa (EBA), the Movement for the Emancipation of the Niger Delta (MEND), emerged in 2005 and Henry Okah (aka Jomo Gbomo) was referred to as the group's leader. However, MEND has no clear hierarchical structure and no single individual in direct control of its subsidiary groups (Tomas, 2010; Egwemi, 2010; Fagbadebo and Akinola, 2010; Ejovi and Ebie, 2013; Oluwaniyi, 2013). These groups combined lethal attacks the sabotage of oil installations with the effective use of global media to publicize their campaign of "fighting for the control of oil revenues by indigenes of the Niger Delta" (Oluwaniyi, 2013). Consequently, the activities of these militant groups led to the militarization of the region by the Nigerian government which yielded no positive result; instead it escalated the crisis in the region.

Nigerian government over the years has tried in one way or the other to curb insurgency in the Niger Delta. In furtherance of government response to curb insecurity and militancy in the Niger Delta region, different institutions and intervention agencies had been set up by successive administrations to mitigate the crisis in the region (Ezeibe and Nnamani, 2010; Ering, Bassey and Odike, 2013). These agencies include;

a. The Niger Delta Development Board (NDDB) established in 1961 by Niger Delta

Development Act (1960) based on the recommendations of the Willink's Commission.

b. The Oil and Mineral Producing Area Development Commission (OMPADEC) created by

Decree 23 of 1992.

c. The Niger Delta Development Commission (NDDC) set up in 2000.

d. The Niger Delta Regional Master Plan launched 27 March 2007, at the end of former President

Obasanjo's 8 years rule.

e. The Ministry of Niger Delta created in 2008.

Despite the creation of these intervention agencies by successive administrations to decisively tackle the fundamental issues involved in oil violence in the Niger Delta region, oil violence and militancy continued 
unabated in the region. Then, in 2009, a combination of military pressure and cash-backed diplomacy by Jonathan (who was then vice president for the administration of Umaru Yar'Adua) produced an amnesty deal with the major militant groups. Thus, the granting of general amnesty to those involved in armed struggle in the region by late President Umaru Musa Yar' Adua on 25 June, 2009 (Ojakorotu and Gilbert, 2010; Orubebe, 2013; Guy 2013; Ajayi and Adesote, 2013). As part of his determination and desire to put an end to the agitations and violence in the region, the late President initiated an Amnesty Programme with the aim of disarming, rehabilitating and re-integrating militants into their communities with a promise to tackle head on, the challenges facing the region (Guy 2013). However, seven years after, the security situation in Niger Delta has dwindled, militancy has resurfaced and oil production has been adversely affected. At this juncture, it is pertinent to ask questions as put forward by Ibaba (2011):

"Does the surrender of arms and renunciation of violence by militants bring the frustration of the entire population to an end? Are the militants the only deprived in Niger Delta? Is the amnesty programme and the attention given to the ex-militants not reinforcing the frustration of those who did not take up arms against the Nigerian state? My answer to the first two is no, but the answer to the third question is in the affirmative. This brings us to the point that violence could rear up or recur in the region if the frustrations which support insurgency are not resolved. Resolving these frustrations is therefore a requirement for peace - building in the region".

\section{The Impact of the Amnesty Programme in Mitigating Insurgency in the Niger Delta}

Prior to the amnesty programme, the Niger Delta region was engulfed with insurgent activities. At its peak in 2009, the insurgency in the Niger Delta cut Nigeria's oil output by over 50 per cent and was costing the government close to four billion naira (nearly $\$ 19$ million) per day in counter-insurgency operations (Crisis Group Africa, 2015). As part of efforts to end insurgency and resolve the protracted insecurity and crisis in Niger Delta, the Federal Government of Nigeria under the leadership of late President Yar' Adua on June 25, 2009, granted unconditional amnesty to the agitators in the region (Aghedo, 2013; Ezeibe and Nnamani, 2010). The term of the amnesty included the willingness and readiness of these agitators to surrender their arms, unconditionally renounce militancy and sign an undertaking to this effect. In return, the government pledged its commitment to institute programmes to assist the disarmament, demobilization, rehabilitation and reintegration of repentant ex-agitators (Ekumaoko, 2013; Ibitoye, 2014). The cardinal objective of granting amnesty to the Niger Delta agitators was to stabilize, consulate and sustain security condition in the region as pre-requisite for promoting economic development in the area and in the country as a whole (Onwukwe, 2013). During the Niger Delta crisis, prior to the Amnesty Programme, the kidnapping of expatriate oil company workers, destruction of oil pipelines, oil theft, illegal bunkering, establishment of illegal refineries and other forms of criminality seriously affected the total production of oil and the revenue the country realized from oil (Garuba, 2012). For over a decade, before the amnesty declaration, the region had been the epicenter of a low intensity conflict owing largely to the insurgency waged by militant youths against Nigerian State and the counter-insurgency by security agents deployed by the state to protect oil resources (Aghedo, 2013).

Obviously, the insurgency waged by the militant groups which had negatively affected oil exploration, production and distribution, and invariably reduced the revenues accruing to the government made the Federal Government to introduce Amnesty Programme in the region in 2009. Thus, the amnesty was designed to ensure peace and reconciliation so as to facilitate uninterrupted oil exploration thereby boosting revenue that would be deployed towards tackling a wide range of problems of underdevelopment in the Niger Delta region (Ajayi and Adesote, 2013). On the other hand, Amnesty Programme was set up to bring peace to the troubled Niger Delta region in order to facilitate oil production. The granting of amnesty to ex-militants initially reduced the spate of violence and invariably increased oil production in the region. It helped to cut attacks on pipelines and restored oil production from 700,000 barrels per day between 2007 and mid-2009 to between 2.4 million and 2.6 million in late 2009 (Oluwaniyi, 2014).

However, the relative peace sustained at the onset of the amnesty programme has dwindled. There has been upsurge of various criminalities such as armed robbery, kidnapping for ransom, oil theft, illegal refining of crude oil, etc., in the region in recent times. In fact the rate of oil theft has imaginary increased and a number of sea piracies have also been recorded in the post amnesty era (Oluwaniyi, 2014; Okurebia and 
Daniel, 2014). Consequently, the initial hope that amnesty programme would bring about sustainable peace in the Niger Delta is now faltering away as the days goes by and the much needed security and development continue to elude the region (Aghedo, 2013). The quest to sustain security in the Niger Delta has remained a major challenge to successive Nigerian governments. In a new development, there have been renewed attacks by new militant groups in the Niger Delta since January 2016. One of the militant groups Niger Delta Avengers (NDA) since its emergence in February 2016 have carried out series of attacks on oil pipelines belonging to Shell, Chevron, NNPC, NPDC and several oil majors operating in the region. The situation has forced some of the oil companies to shut down operations in the area and this have reduced Nigeria's output to a 22-year low. Presently, there is growing concern that further escalation of violence could cripple oil production, with dire, cascading economic and security consequences for the country (Onuoha, 2016). The resurgence of militant groups has clearly shown that the amnesty programme failed woefully to address the inherent causes of violence in the Niger Delta region. Seven years after the declaration of amnesty to the Niger delta militants, the factors that led to militancy are yet to be addressed. Such factors include; widespread poverty, criminal neglect, youth unemployment and environmental degradation.

\section{The Renewed Insurgency in the Niger Delta: Its Implication for Nigeria}

A resurgence of violence and increased oil-related crime in the Niger Delta could seriously undermine national security and economic stability, which is already weighed down by the dwindling oil revenues (Crisis Group Africa, 2015).Rather than hope for a boom in oil prices to lift Nigeria out of its present financial conundrum, the nation appears to be slipping into the old era of bombing and gunfire boom in the oil rich Niger Delta region. The development may spell economic doom for the most populous country in Sub-Sahara Africa. This gloomy challenge is coming barely seven years after Niger Delta militants accepted a Presidential Amnesty Programme (PAP), dropped their arms, in order to pave way for peace and hitch-free oil exploration in the creeks (Alade, Osuyi, Folaranmi, John, \& Ganagana, 2016).

What could be the cause of the continuous attack on oil pipelines in the Niger Delta? There are divergent views as what engendered the renewed insurgency in the Niger Delta. Some analysts have attributed the recent violence in the region to President Buhari's inability to address local grievances in the region. Others have also attributed the reduction in the funding of amnesty programme by 70 percent in the 2016 budget; the termination of ex-militants' pipeline security contracts and the prosecution against the former militant leader, Tompolo, for contract fraud as the causes of renewed insurgency in the Niger Delta region.

In January 2016, unknown criminal elements began attacking oil facilities in the Niger Delta region. In response, President Buhari vowed to deal decisively with the resurgence of oil theft, sabotage of pipelines, and general insecurity (Onuoha, 2016). His threat did not deter the emergence of a new militant separatist group, the Niger Delta Avenger (NDA), which proclaimed its formation on 3 February 2016. Since then, the group has carried out numerous high-profile attacks on oil facilities across the region (Onuoha, 2016). Some of these attacks on oil facilities in the region are shown in the table below.

Timeline of Some Attacks on Oil Facilities in the Niger Delta (January -July, 2016)

January 15, 2016: Militants blew-up major crude oil and gas pipelines to the Chevron Nigeria Limited in Warri South West Local Government Area of Delta state.

January 15, 2016: Militants blew up the Escravos-Warri-Lagos-Abuja gas pipeline and Escravos-WarriKaduna Chevrons pipelines in Warri South West Local Government Area of Delta state.

January 16, 2016: Militant blew up the Abiteye flow station and Sagara to Chevron pipelines in Warri South West Local Government Area of Delta State.

January 17, 2016: Gas pipelines from Olero to Escravos blown up by the militants in Warri South West Local Government Area of Delta State.

January 30, 2016: Gunmen suspected to be ex-militants have attacked a pipeline carrying crude belonging to Italian Oil giant Eni, also known as Nigeria Agip Oil Company (NAOC in Brass Local Government Area (LGA) of Bayelsa State. 
February 10, 2016: NDA militants blew up the Bonny Soku Gas Line, which carries natural gas to the Nigeria Liquefied Natural Gas plant, and an independent power plant at Gbaran, Delta State.

February 13, 2016: NDA Militants attacked the Trans ForcadosPipeline (TFP), which transports oil, water, and associated gas from fields in the western Delta to the 400,000 bpd Forcados oil terminal in Delta State.

May 4, 2016: NDA militants blew up the Chevron Valve Platform located in Warri and Abiteye in Delta state.

May 5, 2016: NDA militants carried out another attacks on the Chevron Well D25 in Abiteye and gas lines feeding the Warri and Kaduna refineries, belonging to the NNPC in Delta State.

May 27, 2016: Niger Delta Avengers, NDA, attacked two separate gas and crude oil pipelines belonging to Chevron ( Escravos Tank Farm - an underground crude oil trunk line and a major electricity gas line) in Ciera creek, near Abiteye community, Warri South-West Local Government Area of Delta State.

May 29, 2016: The NDA militants bombed oil pipeline belonging to the Nigerian Agip Oil Company (NAOC) and another oil firm Aiteo in Nembe and Southern Ijaw Local Government Areas of Bayelsa State.

June 2, 2016: The NDA attacked Chevron's oil wells in Dibi, Warri North Local Government Area of Delta State.

June 9, 2016: NDA militants blew up a major trunk line, Obi Brass, belonging to Agip ENI in Obi Brass, Bayelsa State.

July 6, 2016: Niger Delta Avengers blew up crude oil pipeline, wellhead and manifold belonging to the Nigerian National Petroleum Corporation, NNPC and Chevron Nigeria Limited in Makarava and other parts of Delta State.

July 6, 2016: Niger Delta Avengers blew up NPDC Manifold close to Banta and two PPMC/NNPC crude oil trunk Lines in Batan community, Warri South-West Local Government Area of Delta State.

July 6, 2016: Niger Delta Avengers blew up Chevron Well 10, close to Otunana flow station in Otunana, Delta State.

According to Nigerian National Petroleum Corporation's Group General Managing Director, Maikanti Baru, as at July 2016 the corporation had recorded 1,447 incidences of pipeline vandalism resulting to the loss of millions of litres of products worth billions of naira in 2016 alone. That is a lot to cause pollution! He added that in 2015, Nigeria lost 643 million litres of Premium Motor Spirit valued at N51.3 billion through pipeline vandalism alone (Daniels, 2016)

The group's ability to attack critical nodes of Nigeria's oil infrastructure is attracted serious attention. President Buhari reacted with an aggressive posture, directing the military to "crush the new militant group. The federal government had initially planned a major military offensive to tackle the situation. Troops were massively deployed; heavy arms and ammunition were moved including fighter aircraft. Consequently, the military launched offensive attacks on the Niger Delta communities for the hunt of militant groups behind the new wave of attacks but they registered very little success in terms of stopping explosive attacks on oil and gas facilities. The military invaded Okpelama community, Kurutie, the hometown of Tompolo and Oporoza, the traditional headquarters of Gbaramatu kingdom and other Ijaw communities in Warri South West Local Government Area of Delta State, in search of arms and those responsible for the attacks on oil pipeline facilities. The impact of that military action was terrible on local communities - turning thousands of terrified villagers into refugees (Abayomi, 2016). However, the heavy military presence in the region did not deter the continuous attacks on oil facilities and pipelines by the Niger Delta Avenger. Apparently after realizing the dangers of a full-blown war in the region, the federal governmen adopted conciliatory approach in dealing

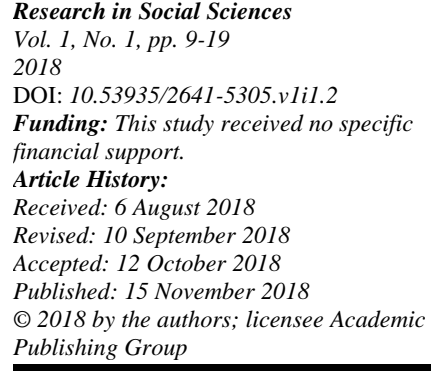


with the militant groups in the Niger Delta (Abubakar, 2016). In June 2016, President Buhari realized that military action would not stop the militants from the onslaught on oil facilities now sued for dialogue with the militants.

The Niger Delta Avengers have become a force to reckon with. Within the short period of their existence, they caused serious havoc to the Nigerian economy by blowing up major pipelines owned by foreign oil companies. Following appeals from prominent Nigerians, notable organisations and pressure groups appealing to them to lay down their arms, the Niger Delta Avengers listed their conditions for peace in the region. The conditions include; immediate implementation of the report of the 2014 National Conference report, failure of which Nigeria will forcefully break-up; President Buhari, the director-general of the State Security Service and the All Progressives Congress (APC) candidate in Bayelsa State, Timipre Sylva should apologize to the people of the Niger Delta region and family of Late Chief DSP Alamieyesegha for killing him with intimidation and harassment because of his party affiliation; the ownership of oil blocks in Nigeria must reflect $60 \%$ for the oil producing people and $40 \%$ for the non-oil producing people and the only Nigerian Maritime University sited in the most appropriate and befitting place - Okerenkoko in Delta State, must start the 2015/2016 academic session immediately (Abubakar, 2016; Alade, Osuyi, Folaranmi, John, \& Ganagana,2016). Other conditions were that the Minister of Transportation, Rotimi Amaechi should apologize to the Ijaws and the entire Niger Delta people for his careless and reckless statement about the location of the University in Okerenko. Also, that Ogoniland and all oil-polluted lands in the Niger Delta must be cleaned up, while compensation should be paid to all oil-producing communities; Radio Biafra director and Independent Peoples of Biafra (IPOB) leader, Nnamdi Kanu, should be released unconditionally; the Niger Delta Amnesty programme must be well-funded and allowed to continue to run effectively; All APC members indicted for corruption should be made to face trial like their counterparts in the Peoples Democratic Party and all oil multi-nationals and foreign investors should observe this demands, as their business interest in the country will be first targeted (Abubakar, 2016; Alade, Osuyi, Folaranmi, John, \& Ganagana, 2016).

In a new twist, the Niger Delta Avengers, in a statement said that their goal is now the actualization of a sovereign state of Niger Delta. Projecting into the months ahead, they vowed that by October 2016, they would display their Currency, Flag, Passport, Ruling Council and Territory to the world. They also requested the United Nations to support their mission in order to free the people of the Niger Delta from environmental pollution, slavery, and oppression. They want a country that will turn the creeks of the Niger Delta to a tourism heaven, a country that will achieve its full potentials, a country that will make health care system accessible to everyone. With Niger Delta still within Nigeria, that cannot be possible (Alade, Osuyi, Folaranmi, John, and Ganagana, 2016). The group's conditions for peace expose the multi dimensional reality of the group's agitation. The Niger Delta Avengers claimed to be fighting for the development of the region. On the contrary, several of its conditions for a truce are on issues outside the area. At one breath the group sounds as being motivated by the plight of the ordinary citizens in the oil communities, in another breath, they are political and at times secessionist (Abubakar, 2016).

On the other hand the bombing of oil pipeline and other facilities belonging to Shell, Chevron, NNPC, NPDC and several oil majors operating in the region by the Niger Delta Avenger forced some of the oil companies to shut down operations in the area. Nigeria lost about 140,000 barrels of crude daily, translating to a loss of $\$ 6.72 \mathrm{~m}$ (about N1.3 billion) due to the attacks on oil installations by Niger Delta Avengers. Aside the heavy loss in revenue accruals to the federation, sustained attacks on gas pipelines has led to drop in power generation. During the onslaught, electricity generation dropped to 'zero megawatts' several times (Abubakar, 2016). Thus, the attacks on oil facilities by the Niger Delta Avengers had multiplier effects. Attacks on crude pipelines shut down refineries, attacks on export terminals affects oil exports and attacks on gas pipelines shut down power plants. This strategy ensures that one attack has a ripple effect beyond the Delta and it's been felt by ordinary Nigerians. In same vein, Onuoha (2016) elaborated on the impact of attacks on oil pipelines by the Niger Delta Avenger in the region. According to him:

Research in Social Scienc
Vol. 1, No. 1, pp. 9-19 2018

DOI: 10.53935/2641-5305.v1i1.2

Funding: This study received no specific financial support.

Article History:

Received: 6 August 2018

Revised: 10 September 2018

Accepted: 12 October 2018

Published: 15 November 2018

(C) 2018 by the authors; licensee Academic Publishing Group
"The renewed attacks by militant groups not only undermine Nigeria's economic stability, but also risk exacerbating maritime insecurity in the Gulf of Guinea $(G o G)$. Owing to recent attacks on critical infrastructure, Nigeria's oil production has plummeted from 2.2 million bpd to about 1.4 million bpd. Nigeria is already losing about N2.79 billion ( $\$ 14$ billion) daily to the closure of the ExxonMobil-operated Qua Iboe terminal, following the evacuation of Exxon-Mobil's workers. 
This has compounded government revenue losses caused by the fall in global oil prices since mid2014. In addition to crippling oil exports, the new wave of militancy in the Delta has also choked the supply of gas to local power plants, thus hobbling Nigeria's power grid. Electricity generation in Nigeria has declined from about 4,800 megawatts in August 2015 to 1,000 megawatts in May 2016. This has seriously undermined overall productivity and service delivery in the economy. The renewed violence has also impacted maritime security in the GoG. Pirate attacks emanating from the Niger Delta remain a major threat to the oil industry in Nigeria and merchant shipping in the GoG. An estimated 70 percent of all piracy-related incidents in the GoG are directly related to Nigerian criminal gangs, mostly originating from the Niger Delta. In the first quarter of 2016, at least 12 attacks were recorded in the Gulf of Guinea, including nine in Nigeria, one in Côte d'Ivoire, and two within the territorial waters of the DR Congo"

The recent uprising of militant groups particularly the Niger Delta Avenger that is more daring, depicts that violence in the Niger Delta may escalate unless the Nigerian government acts quickly and decisively to address long-simmering grievances. With the Presidential Amnesty Program for ex-insurgents due to end soon, there are increasingly bitter complaints in the region that chronic poverty and catastrophic oil pollution, which fuelled the earlier rebellion, remain largely unaddressed (Crisis Group Africa, 2015).

\section{Concluding Remarks and the Way Forward}

The Niger Delta people have endured a long pain of economic, political, and social injustice over the oil resource in their community (oil-bearing communities) which they should ordinarily be getting royalty from the multinational corporations and subsequently paying tax to the federal government, based on a true federal composition of the country. Contrary to this, environmental damage from oil exploration as a result of oil spillage, unemployment, poverty, violation of fundamental human rights, destruction of farm land and many more are all that the Niger Delta people could get in return for God's kindness that makes them oil-bearing communities (Abegunde, 2013). The incontrovertible fact is that both the federal government and the multinational oil companies were grossly negligent for too long about the welfare of the people and the communities of the oil bearing areas of the region (Efeturi, 2016). The latest brazen and simultaneous attacks on oil and gas facilities by the Niger Delta Avenger have shown that the Amnesty programme is not the solution to the Niger Delta problem. It has not been able to solve the problems of poverty, environmental degradation, and massive youth's unemployment.

Therefore, to avert another phase of full-scale insurgency in the region, the Federal Government should muster the political will to address the following challenges that led to insurgency; inadequate infrastructure, environmental pollution, widespread poverty, youth unemployment and local demands for a bigger share of oil revenues.

- In the area of inadequate infrastructure, the Federal Government should increase development funding in the region and also monitor the implementation of development projects to ensure they achieve the desired outcomes. The government should upgrade and enhance health facilities, education, housing, water supply and road infrastructure of the Niger Delta and also the provide facilities and infrastructure for water, rail and air transportation of people and goods across the region.

- In term of human capacity building, the Federal Government and state governments in the region should empower the youth in skill acquisition programmes, grant scholarship to those who wish to further their education and create Job opportunities for the teeming unemployed youths. In line with this, oil companies should also intensify efforts to create jobs for local youth by increasingly outsourcing marginal jobs to local companies and utilising local materials and expertise in compliance with the Nigerian Oil and Gas Industry Content Development Act. Also, ex-militants who had been trained should be engaged by the oil companies operating in the region.

- Federal government should immediately commence the clean-up of all oil-polluted lands and waters in the region pay compensation to those communities whose lands and waters were polluted and also take urgent steps to stop further environmental degradation in the Niger Delta. 
- There should be an inclusive participation in oil industry and ownership of oil blocs. The federal government should enunciate policies and actions that will address the lack of participation as well as imbalance in the ownership of oil and gas assets.

\section{References}

Abayomi, J. (2016). Pipelines bombings: Soldiers invade Gbaramatu in search of militants. Vanguard. Available from http://www.vanguardngr.com/2016/01/soldiers- invade-delta-community-in-search-of-militants/

Abubakar, A. (2016). Terror in the creeks: Rise of Niger Delta Avengers.Masterweb Reports. Available from http://nigeriamasterweb.com/Masterweb/breakingnews-10716-terror-creeks-rise-niger-delta-avengers

Aghedo, I. (2013). Winning the War, Losing the Peace: Amnesty and the Challenges of Post Conflict Peace-building in the Niger Delta, Nigeria. Journal of Asian and African Studies, 48(3): 267-280.

Alade, A., Osuyi, P., Folaranmi, F., John, T., \& Ganagana, M. (2016). Niger Delta Avengers: The Return of Full-Blown Militancy. The Sun. Available from http://sunnewsonline.com/niger-delta-avengers-the-returnof-full-blown-militancy/

Amaize, E. (2016). Militants blow flow station, Chevron pipelines. Vanguard. Available from http://www.vanguardngr.com/2016/01/militants-continue-bombing-in-delta/

Amaize, E. (2016). Return of N-Delta Militancy? Major crude oil, gas pipelines bombed. Vanguard. Available from http://www.vanguardngr.com/2016/01/return-of-n- delta-militancy-major-crude-oil-gas-pipelines-bombed/

Badmus, I. A. (2010). Oiling the Guns and Gunning for Oil: Oil Violence, Arms Proliferation and the Destruction of Nigeria's Niger-Delta. Journal of Alternative Perspectives in the Social Sciences. 2(1), 323-363.

Crisis Group Africa (2015). Curbing Violence in Nigeria (III): Revisiting the Niger Delta, Crisis Group Africa Report $\mathrm{N}^{\circ} 231,29$ September.

Daniels, B. (2016). ANALYSIS: Niger Delta Bomb Attacks: The Search For Motives, Premium Times. Available From http://www.premiumtimesng.com/business/business-data/216485-analysis-niger-delta-bomb-attacks-searchmotives.html

Efeturi, L. D. (2016). Resolving Militancy in the Niger Delta. Premium Times.

Available from http://opinion.premiumtimesng.com/2016/06/10/militancy-niger-delta-facts- fallacies/

Egwemi, V. (2010). From militancy to amnesty: Some thoughts on President Yar Adua's approach to the Niger Delta crisis.Current Research Journal of Economic Theory, 2(3): 136-141

Ejovi, A.,\& Ebie .C. S. (2013).Niger Delta: A Critical Appraisal of the Amnesty Programme and Social Political Development in Nigeria. Research on Humanities and Social Sciences, 3(22): 130-138.

Ekumaoko, C.E. (2013). The Amnesty Question in Post Conflict Niger Delta and Peace-Building. Arabian Journal of Business and Management Review, 2(10): 1-12.

Ering, S.O., Bassey, G. E. \& Odike, E.L. (2013). The Niger Delta Crisis in Nigeria: Pre and Post Amnesty Situation. Mediterranean Journal of Social Sciences, 4(6): 421-427.

Ezeibe, C.,\& Nnamani, D.O. (2010). National Security and President Yar' Adua Amnesty Programme in the Niger Delta. A Political Economy of Peace Making Process. Journal of Social Source and Public Policy, 2(2): 107 114

Fagbadebo, M. O. \& Akinola, O. A. (2010). Post-Amnesty Niger Delta and the Promise of Development: Issues, Prospects and Problems, From the Selected Works of OmololuMichael Fagbadebo, Available at: http://works.bepress.com

Ibaba, I.S. (2011). Amnesty and Peace - Building in the Niger Delta. Addressing the Frustration -Aggression Trap. African: The Niger Delta (Special Issue), 5(1): 238-271.

Ibitoye, D. (2014). A look into the Niger Delta Amnesty Program- Success or Failure? Available from https://ndlink.org/a-look-into-the-niger-delta-amnesty-program-success-or-failure

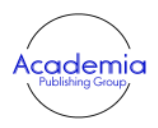

Research in Social Sciences Vol. 1, No. 1, pp. 9-19 2018

DOI: $10.53935 / 2641-5305 . v 1 i 1.2$

Funding: This study received no specific

financial support.

Article History:

Received: 6 August 2018

Revised: 10 September 2018

Accepted: 12 October 2018

Published: 15 November 2018

(C) 2018 by the authors; licensee Academic Publishing Group

Ikelegbe, A. (2010).Oil Resource Conflicts and Post Conflict Transition in the Niger Delta Region: Beyond the Amnesty. Benin City: Centre forPopulation and Environmental Development (CPED) monograph series, No.3

Ikelegbe, A. \& Umukoro, N. (2014). Exclusion and the Challenges of Peace Building in the Niger Delta: An Assessment of the Amnesty Programme. Benin City: Centre for Population and Environmental Development (CPED) Monograph series, No.11

Kimiebi, I. E. (2010). Oil, Militancy and Political Opportunities in Niger Delta. [Web log post]. Available from http://www.kimiebi.blogspot.com

Obi, C.,\& Rustad, A. S. ( 2011). Introduction: Petro-Violence in the Niger Delta-The Complex Politics of an Insurgency" Cyril Obi and Siri Aas Rustad (eds), Oil and Insurgency in the Niger Delta: Managing the complex Politics of Petro-Violence. London: Zed Books

Obi, C.I. (2010). Oil Extraction, Dispossession, Resistance and Conflict inNigeria's Oil-Rich Niger Delta, Canadian Journal of Development Studies 30(1-3): 219-236. 
Ojakorotu, V. \& Gilbert, D.L. (2010). Understanding the Context of Oil Violence in Niger Delta of Nigeria: in Ojakorotu, V.\& Gilbert, D.L (Eds.) Checkmating the Resurgence of Oil Delta of Nigeria. Johannesburg

Ojo, S. (2012). Amnesty Programme, Niger Delta Militancy and the Place of Trust. International Journal of Service and Knowledge 1(1): 38-46

Okoli, A. C. (2007). Group Dynamics and the Dialectics of Stability in the Niger Delta. A Paper Presented At The 7th Annual Conference of Nigerian Sociological Society.

Okoli, A. C. (2013). The Political Ecology of Niger Delta Crisis and Prospects of Lasting Peace in The Post-Amnesty Period. Global Journal of Human Social Science,13(3): 36-46.

Okurebia, S.,\& Daniel, E. (2013). Management of Amnesty Programme for Sustainable Livelihood in the Niger-Delta Region of Nigeria:Challenges and Policy Action. Journal of Business and Management (IOSR-JBM), 14(3): 3642

Oluduro, O.,\& Oluduro, O.F. (2012). Nigeria: In Search of Sustainable Peace in the Niger Delta through the Amnesty Programme. Journal of Sustainable Develoment, 5(7): 48-61.

Oluwadare, J. A \& Oyebode, O. M. (2013). Oil Resource as a Major Source of Insecurity in the Niger Delta of Nigeria. Research on Humanities and Social Sciences, 3(21): 32-44.

Oluwaniyi, O. O. (2013). Post -Amnesty Programme in the Niger Delta: Challenges and Prospects Available from http://En.Wikipedia.Org/Wiki/Political Ecology

Oluwaniyi, O.O. (2014).Post-Amnesty Reintegration and Peacebuilding Challenges in Nigeria's Niger Delta Region:The Way Forward. New York, USA:The Social Science Research Council (SSRC).

Onuoha, C. F. (2016) The Resurgence of Militancy in Nigeria's Oil-Rich Niger Delta and the Dangers of Militarisation. Reports, Ajazeera Centre for Sudies, pp: 1-9.

Onwukwe, D. (2013.). 4 Years of Amnesty in Niger Delta: The Pains, the Gains. The Sun. Available from http://sunnewsonline.com/new/cover/4-years-of-amnesty-in-ndelta-the-pains-the-gains/

Orubebe, P.G. (2013, March 11).Challenge of Regional Development in Nigeria: The Case of Niger The Source, 32(21).

Tonwe, A. D.,\& Aghedo, I. (2013). Amnesty for Sustainable Peace and Development in Nigeria's Niger Delta Region: Panacea or Palliative? Journal of Sustainable Development in Africa, 15(5-6). 